\title{
Monitoring the impact of intensive shallow geothermal energy use on groundwater temperatures in a residential neighborhood
}

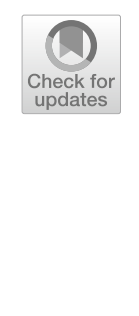

\author{
Thomas Vienken $^{1 *}\left(\mathbb{D}\right.$, Manuel Kreck ${ }^{1}$ and Peter Dietrich ${ }^{1,2}$
}

*Correspondence:
thomas.vienken@ufz.de
${ }^{1}$ UFZ-Helmholtz Centre
for Environmental Research,
Leipzig, Germany
Full list of author information
is available at the end of the
article

${ }^{*}$ Correspondence: thomasvienken@ufzde for Environmental Research Leipzig, Germany article

\begin{abstract}
The use of shallow geothermal energy increasingly receives attention as a suitable alternative to fossil fuel-based space heating and cooling, warm water provision, as well as for seasonal heat storage throughout Europe. With the advent of shallow geothermal energy use on large scales, a vivid discussion of potential ecological and economic impacts has arisen but actual field data are scarce. An intensive groundwater temperature-monitoring program over a period of 3 years with consecutive measurements was, therefore, initiated at a residential neighborhood in the city of Cologne, Germany, under intense shallow geothermal use. The aim of the monitoring program was to overcome the existing data scarcity by pinpointing the effects of the intensive thermal use of the subsurface on groundwater temperatures and to foster understanding of urban groundwater temperature evolution. Results show that even though energy demands of the individual houses and energy extraction rates of the shallow geothermal systems were comparably small in this case, the accumulation of shallow geothermal users had a measurable impact on overall groundwater temperatures.
\end{abstract}

Keywords: Shallow geothermal energy, Thermal impact, Urban groundwater temperatures

\section{Introduction}

Households accounted for $25.4 \%$ of the final energy consumption in the EU 28 in 2016 of which almost $80 \%$ of that energy was used for space heating and warm water provision (see Eurostat 2018). At the same time, only $16 \%$ of the final energy consumption of households was derived from renewables, including the renewable part of waste (see Eurostat 2018). Hence, strengthening the share of renewables for space heating and warm water provision is an important piece of the puzzle for the decarbonization of the building sector that plays an important role in reducing global greenhouse gas emissions (Lucon et al. 2014). The use of shallow geothermal energy has increasingly received attention as suitable alternative to fossil fuel-based space heating and cooling, warm water provision, as well as for seasonal heat storage over the last 20 years, e.g., see Sanner (2017) for the development of the German ground source heat pump market. This is because ground source heat pump technology can readily be used to provide sufficient space heating during winter periods even at locations that are not favored by an

(c) The Author(s) 2019. This article is distributed under the terms of the Creative Commons Attribution 4.0 International License (http://creativecommons.org/licenses/by/4.0/), which permits unrestricted use, distribution, and reproduction in any medium, provided you give appropriate credit to the original author(s) and the source, provide a link to the Creative Commons license, and indicate if changes were made. 
elevated geothermal gradient (e.g., Sanner et al. 2003; Hähnlein et al. 2010 and references therein). Shallow geothermal installations extract heat from the subsurface during heating season. Therefore, open and closed systems are used. Open installations directly use groundwater via pumping and injection wells as geothermal heat source while in closed systems, such as borehole heat exchangers, a heat transfer fluid is circulated through a pipe system to transfer the thermal energy from the subsurface to the heat pump. The heat pump then elevates the temperature in the heat distribution cycle to a level that is sufficient for space heating and warm water provision. Alternatively, buildings can be cooled by transferring the accumulated heat in buildings into the subsurface. Hence, the use of shallow geothermal energy directly impacts the subsurface temperature regime (see Hein et al. 2016 among many others). Further information about shallow geothermal energy use is provided amongst others by Sanner et al. (2003) and Lund et al. (2004).

More than 1.7 million ground source heat pump systems with a capacity of over 20 GWth were operated in Europe by the end of 2015 (EGEC 2017). With the advent of intensive shallow geothermal energy use, a vivid discussion of the ecological as well as economic sustainability of the intensive thermal use of the shallow subsurface has arisen. Since groundwater represents the major source of drinking water in many European countries (Margat and van der Gun 2013), there is regulatory concern for any negative effects in regards to groundwater quality. Main concerns are potential impacts of significant groundwater temperature changes on geochemical (e.g., Hartog 2011; Bonte 2013; Possemiers et al. 2014; Park et al. 2015; Garrido Schneider et al. 2016) and biological groundwater properties (e.g., Brielmann et al. 2009; Lerm et al. 2011; Griebler et al. 2015; Lienen et al. 2017; Westphal et al. 2017). Growing awareness is furthermore dedicated with respect to conflicting subsurface use (e.g., Quattrocchi et al. 2013) as well as conflicts among geothermal users (Ferguson and Woodbury 2006; Younger 2008; Bakr et al. 2013). Latter is especially important when considering that changes in initial groundwater temperatures directly lead to changes in geothermal heat pump efficiency (Pärisch et al. 2014); i.e., a decrease of groundwater temperatures causes a decrease of heat pump efficiency during heating operation. Hence, knowledge about subsurface temperature distribution and evolution is important for the ecological and economic sustainable intensive thermal use of the shallow subsurface and management of shallow geothermal resources (e.g., Epting et al. 2013; Vienken et al. 2015). Respective research focuses mainly on the assessment and prediction of local groundwater temperature evolution and resulting impacts in the vicinity of large scale installations (e.g., Bauer et al. 2015; Boockmeyer and Bauer 2016) as well as monitoring of groundwater temperature distribution on city scale to detect and quantify the anthropogenic heat impact, i.e., formation of urban groundwater heat islands (e.g., Zhu et al. 2010). Investigations on neighborhood scales are scarce because individual system sizes are small and monitoring is hence often not required. Furthermore, density of public groundwater monitoring wells is in many cases not sufficient on this scale (e.g., see Menberg et al. 2013a for groundwater temperature-monitoring location distribution in different German cities). This highlights one of the major problems in urban geothermal development: While the individual system capacities are small, the heating/cooling capacity of residential neighborhoods easily accumulates to comparable values of large-scale projects of several hundred kW's while groundwater temperature evolution is in many cases unknown. Numerical models are 
frequently used to predict and visualize induced groundwater temperature changes and potential system interaction. The constant advancement of simulation tools and computational power allow meanwhile investigations on various scales (Boockmeyer and Bauer 2016; Hein et al. 2016). However, the lack of monitoring data (heat pump operation and groundwater temperature data) for model parametrization and calibration as well as the lack of reliable exploration data with resulting oversimplification of the geological and hydrogeological regime lead to resulting simulation uncertainties in practice (e.g., Schelenz et al. 2017; Hermans et al. 2018)—making exploration and actual groundwater temperature monitoring indispensable.

This study aims to overcome the existing data scarcity by pinpointing the effects of the intensive thermal use of the subsurface on neighborhood scale at the presented case study site. Therefore, groundwater temperatures were intensely monitored at a residential neighborhood under intensive shallow geothermal use in the city of Cologne, Germany, over a period of 3 years with consecutive measurements of several month durations. Although heat exchange along borehole heat exchangers occurs in the unsaturated and saturated zone, we focus on induced effects on groundwater temperatures because wider impact ranges are expected within the saturated zone and temperatures changes within the groundwater are at the forefront of regulatory awareness. Against this background, all relevant data are provided as Additional file 1. We thereby want to foster understanding of urban groundwater temperature evolution and encourage further work of reliably predicting the induced groundwater temperature changes as a prerequisite for the ecological and economic sustainable intensive thermal use of the shallow subsurface on neighborhood scale. We further identify and address difficulties and challenges that were encountered during the planning and execution of this groundwater temperature-monitoring campaign. This provides valuable insights for all who work with groundwater temperature data but may not be directly involved in data acquisition.

\section{Test site}

The test site is located in the western part of the city of Cologne, Germany, and has an approximate size of $0.1 \mathrm{~km}^{2}$. It was selected based on the following criteria: (a) high shallow geothermal usage density over a clearly delimited area (see Fig. 1); (b) layout of neighborhood ideal in respect to presumed groundwater flow direction; (c) opportunity for installation of an appropriate monitoring network; and, (d) availability of shallow geothermal system data. Information on shallow geothermal installations and individual heat demands was obtained from the publicly available city's water books. Fifty out of 165 houses within the premises of the test site are supplied with shallow geothermal energy of which 47 houses use borehole heat exchangers systems for heat generation and 3 houses use open systems for heating and cooling. Eight pumping and injection wells for the 3 opens systems as well as 303 individual borehole heat exchangers with a total length of 11,009 $\mathrm{m}$ were installed during a refurbishment of the residential area starting in 2008 to satisfy the total heat demand of $506 \mathrm{~kW}$ for these 50 houses. This means a number of systems were already in operation before the start of the presented monitoring campaign in 2013. The approved cooling demand of $<50 \mathrm{~kW}$ of the open systems (approximated as not all data were available) 


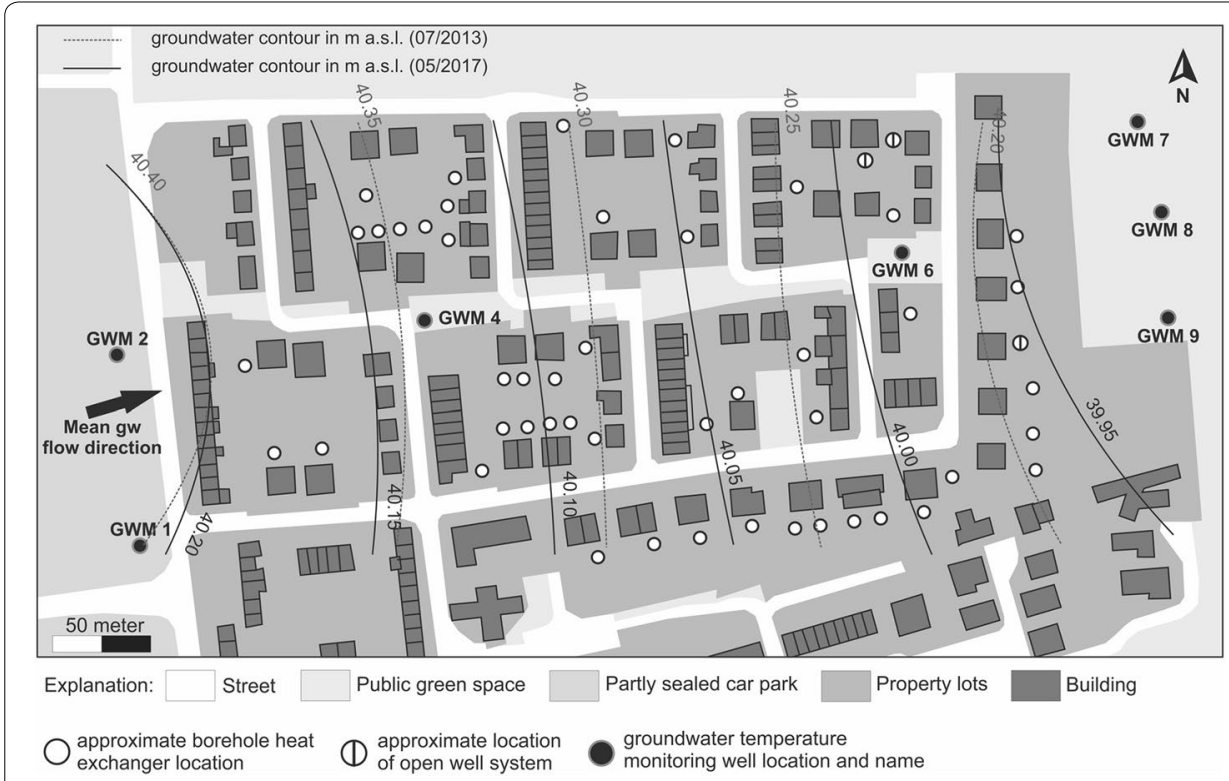

Fig. 1 Overview of the test site with locations of groundwater temperature-monitoring wells and shallow geothermal systems

is small compared to the total heat demand and the potential of superimposed thermal signals during heating and cooling cycles is hence assumed negligible. Borehole heat exchanger systems are not foreseen for cooling. The low number of open systems is, in addition, beneficial for this study to minimize impacts from pumping on the groundwater flow field. The average heat demand per house using borehole heat exchanger system is $9.6 \mathrm{~kW}$. Considering an average total installation length of $234 \mathrm{~m}$ per borehole heat exchanger system an average heat extraction capacity of $41 \mathrm{~W} / \mathrm{m}$ can be presumed.

The subsurface of the test site is composed of sand and gravel deposits of the Quaternary terrace layers of the Rhine River which are overlain by loam deposits; see Klostermann (1992) for an overview of the stratigraphy and hydrogeology in the Cologne area. Soil profiles obtained during borehole heat exchanger installation indicate a local thickness of the Quaternary layers of 30-40 m to which the use of shallow geothermal energy is restricted to at the test site. The transition between Quaternary and Tertiary is described in literature by fine sand deposits with reduced hydraulic conductivity (Losen 1984). The groundwater flow was reported to be directed in a west-northwesterly direction towards the Rhine River as major receiving stream at about $6.5 \mathrm{~km}$ distance. The shallow average installation depth of $37 \mathrm{~m}$ for borehole heat exchanger systems at the test site allows a generally good accessibility of the subsurface for exploration and monitoring. Despite large investments (a total of 750,000 EUR assuming an average price of 15,000 EUR per system) for the installation of 50 shallow geothermal heating systems, site-specific information on the groundwater regime was not collected before the geothermal development. A direct push (see site investigation section) site investigation was subsequently performed to obtain additional information on local hydrogeological conditions, on the local thickness of the overlying loam layer, and for the enhanced 
Table 1 Estimated hydraulic conductivities at GWM locations 3 and 6

\begin{tabular}{lll}
\hline GWM location & Measurement depth in mbgs & $\begin{array}{l}\text { Estimated hydraulic } \\
\text { conductivity in } \mathbf{~ m} / \mathbf{s}\end{array}$ \\
\hline 3 & 26.00 to 27.06 & $9.13^{*} 10^{-04}$ \\
3 & 28.00 to 29.06 & $5.37^{*} 10^{-04}$ \\
3 & 29.06 to 30.12 & $5.65^{*} 10^{-04}$ \\
6 & 27.40 to 28.46 & $6.16^{*} 10^{-04}$ \\
6 & 28.90 to 29.96 & $8.03^{*} 10^{-04}$ \\
\hline
\end{tabular}

characterization of the Quaternary terrace deposits prior to the installation of the groundwater temperature-monitoring network. Detailed information on the site investigation is provided in the following section.

\section{Site investigation}

Direct push technology was used for the characterization of the shallow subsurface at the test site. Direct push refers to a technique used for performing geotechnical, geophysical, geochemical, and/or hydrogeological subsurface investigations by driving, pushing, and/or vibrating small-diameter hollow steel rods into the ground (EPA 1997). The use of direct push was beneficial as the mobile direct push equipment could be maneuvered easily between existing building infrastructure and trees in public green spaces. Moreover, the advantage of direct push technology over conventional drilling techniques is that quasi-continuous in situ information about the vertical distribution of soil-specific properties, e.g., information about local stratigraphy and hydrogeological properties, can be rapidly obtained by attaching sensor probes at the end of the rod string; see Butler (2005), Dietrich and Leven (2006), Leven et al. (2011), Vienken et al. $(2012,2013)$ for further information on the used direct push tools.

The following site investigation approaches were used to obtain detailed subsurface information:

- Soil coring with a diameter of $5 \mathrm{~cm}$ at groundwater monitoring well (GWM) locations 2, 5, and 6 (see Fig. 1) to a depth of $24.2 \mathrm{mbgs}, 21.5 \mathrm{mbgs}$, and $11.75 \mathrm{mbgs}$ was performed for stratigraphic subsurface characterization and laboratory measurements of thermal conductivity on soil samples.

- Local thickness of the overlying loess-loam layer was determined by the combined use of direct push electrical conductivity profiling and the hydraulic profiling tool. Furthermore, this direct push approach allows identification of different hydrostratigraphic units and detection of potential clay-bearing layers/horizons. Investigations were performed at GWM location 1 (max. depth $30.68 \mathrm{mbgs}$ ), GWM location 3 (max. depth 31.08 mbgs), GWM location 4 (max. depth 26.63 mbgs), and GWM location 6 (max. depth 30.86 mbgs).

- Pneumatic slug testing was used to obtain information about hydraulic conductivity of hydrostratigraphic units; slug tests were performed in temporary installed direct push monitoring wells with a diameter of $12 \mathrm{~mm}$ and a screen length of $1.06 \mathrm{~m}$ at GWM location 3 and GWM location 6 (see Table 1). Slug tests were analyzed after Zlotnik and McGuire (1998) and Butler (1997). 


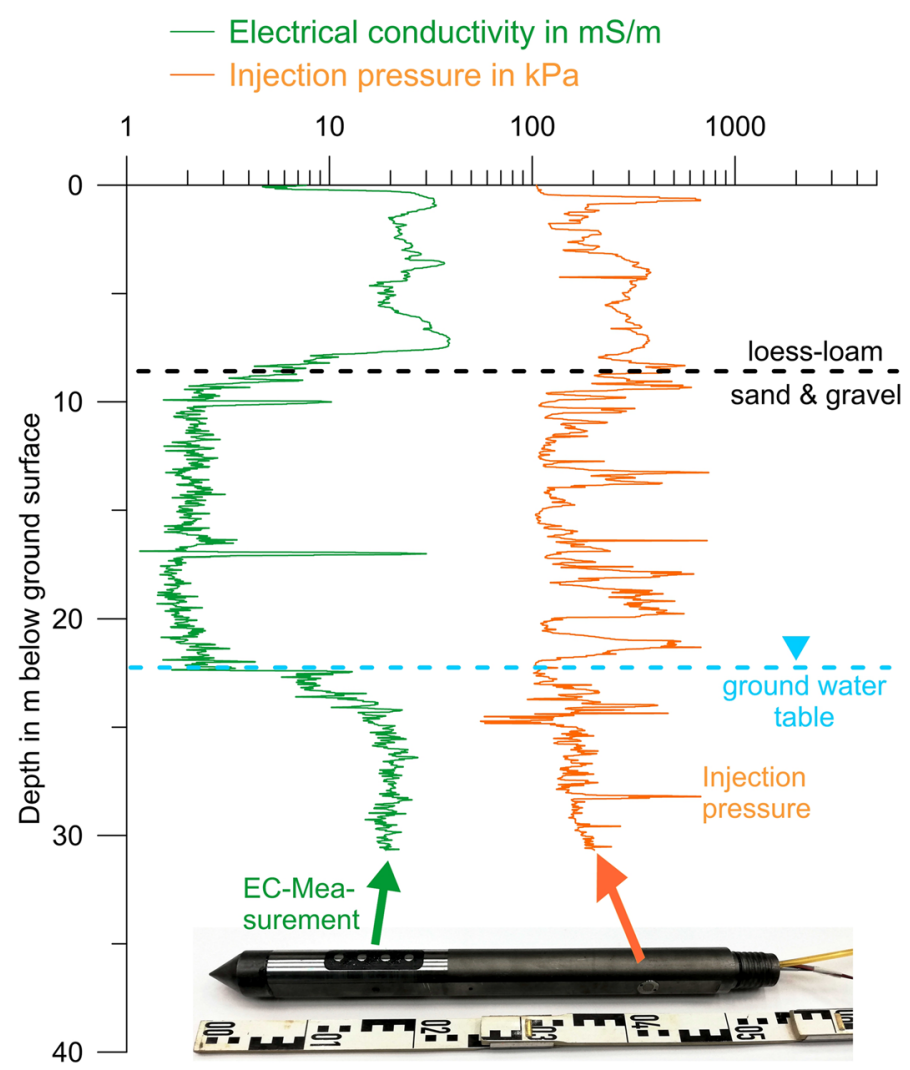

Fig. 2 Overview of the employed direct push probe and direct push hydraulic profiling and electrical conductivity logging results at well location 1

Sand and gravel deposits restricted direct push profiling to the aforementioned depths. However, sufficient information about the thickness of the loess-loam layer and relevant matrix properties for the Quaternary terrace layer was collected to complement the existing literature and drilling information. An average thickness of $8 \mathrm{~m}$ was determined for the loess-loam layer across the test sites in the course of the site investigation. Results of the direct push vertical hydraulic profiling did neither indicate the presence of layers with distinct differences in hydraulic properties nor the presence of distinct clay layers within the aquifer; see Fig. 2 for an exemplary overview of direct push investigations results at well location 1 . An average hydraulic conductivity of $6.87^{*} 10^{-4} \mathrm{~m} / \mathrm{s}$ was determined for the Quaternary terrace layer based on the arithmetic mean of five individual slug test depths at GWM locations 3 and 6 (see Table 1). An average thermal conductivity value of $0.5 \mathrm{~W} /\left(\mathrm{m}^{*} \mathrm{~K}\right)$ for dry material and $3.3 \mathrm{~W} /\left(\mathrm{m}^{*} \mathrm{~K}\right)$ under saturated conditions was determined for the Quaternary terrace layer based on the geometric mean of eight repeat measurements under different sample compaction (Lindner 2015). During the investigation, a groundwater table of $22.25 \mathrm{mbgs}$ at GWM 2 and a low hydraulic gradient of 0.0005 to 0.0006 were observed across the test site (see groundwater table contour lines for July 2013 and May 2017 in Fig. 1), leading to an approximate Darcy velocity is 10.8-13 m per year. Recorded groundwater head data are provided in the supplement. 


\section{Groundwater temperature-monitoring network}

Seven groundwater temperature-monitoring wells were installed, i.e., two wells upstream of the test site, two wells within the neighborhood, and three monitoring wells downstream of the test site (see Fig. 1). Due to the compact sand and gravel deposits direct push-based well installation depths of approximately $30 \mathrm{~m}$ below ground surface were achieved. Wells were screened over the encountered saturated thickness (ca. $8 \mathrm{~m}$ screen length). Groundwater temperature-monitoring well 4 (see Fig. 1) could only be installed to a final depth of $25.8 \mathrm{~m}$ below ground surface with a filter length of $4 \mathrm{~m}$. Although the mean borehole heat exchanger installation depth of $37 \mathrm{~m}$ was not reached with the monitoring wells, numerical simulation of the temperature distribution along borehole heat exchanger arrays under the encountered conditions show that investigation depths of $30 \mathrm{~m}$ are sufficient to capture the characteristic induced groundwater temperature changes at the site (Schelenz 2017). Particular attention was paid to well design, i.e., small well diameter, to minimize well-induced effects (e.g., free convection) and similarity of the wells to allow maximum comparability of the measurements. Insofar technically possible within the compact sand and gravel deposits, $1.25^{\prime \prime}$ outer diameter PVC monitoring wells were installed and equipped with Tidbit v2 (Onset Computer Corporation) autonomous temperature logging devices in $0.5 \mathrm{~m}$ vertical spacing within the saturated zone. At GWM location 1 and 6, penetration resistance of the soil only allowed installation of $1^{\prime \prime}$ outer diameter PVC monitoring wells, that were equipped with regular groundwater loggers of smaller diameter, recording groundwater level, temperature, and electrical conductivity. Due to the significantly higher costs in comparison to the Tidbit loggers, these loggers could be installed only at selected depths. A total of 35 Tidbit temperature loggers were initially installed in the five $1.25^{\prime \prime}$ wells and seven regular loggers were installed in the two $1^{\prime \prime}$ wells. In addition, four of the $1.25^{\prime \prime}$ wells were equipped with groundwater loggers to monitor groundwater head elevation. Direct Push $1.25^{\prime \prime}$ pilot holes at well locations 1 and 6 that did not reach the groundwater were used to install soil temperature-monitoring wells. Therefore, solid PVC pipes were installed to a depth of $17.3 \mathrm{mbgs}$ at well location 1 and $19.2 \mathrm{mbgs}$ at well location 6. PVC pipes within the unsaturated zone were filled with water and Tidbit loggers were installed at selected depths to capture the vertical distribution and temporal evolution of soil temperatures. At this point it should be mentioned that soil temperature measurements taken at well location 1 could not be interpreted because of surface water inflow into the monitoring well. Groundwater temperature evolution at the site was monitored from April 24th, 2013 to May 11th, 2016 with groundwater temperatures being logged every $4 \mathrm{~h}$ across the site. Two consecutive measurement campaigns followed from January 13th, 2017 to May 22nd, 2017 as well as from March 13th, 2018 to June 30th, 2018.

\section{Results and discussion}

Since considerable efforts for well installation and logger calibration were made, a long-term temperature drift was observed for one logger installed in the $1^{\prime \prime}$ groundwater temperature-monitoring well 1 and for the four loggers installed in the $1^{\prime \prime}$ groundwater temperature-monitoring well 6 . This drift was detected during laboratory logger calibration and subsequently quantified by comparing calibration results of the loggers in calibration temperature baths at different dates. The data were offset 


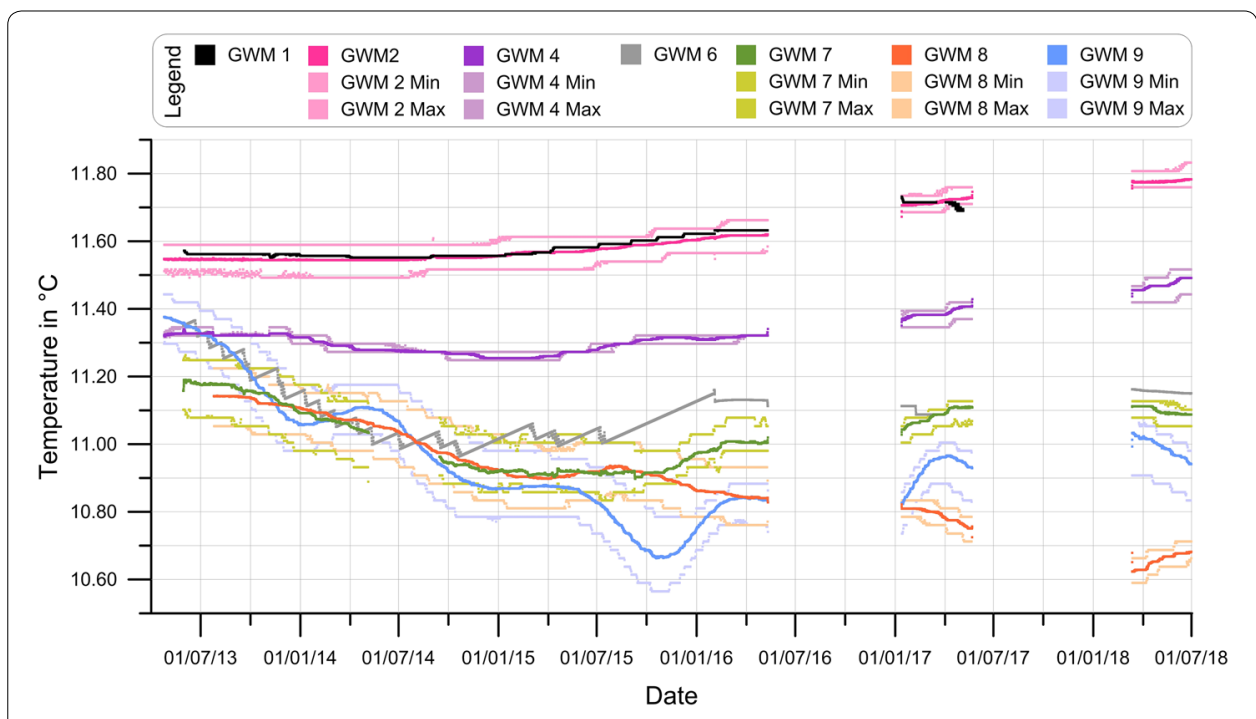

Fig. 3 Evolution of measured groundwater temperatures between April 2013 and June 2018

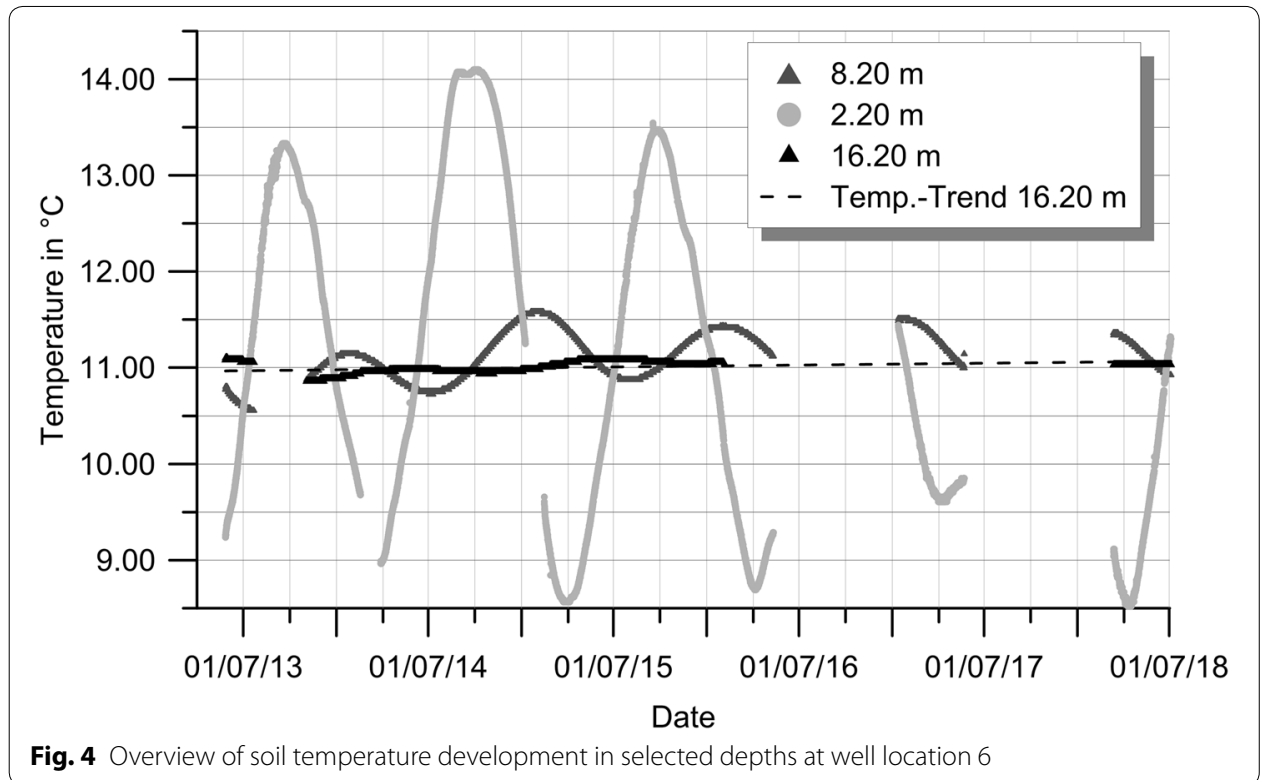

corrected assuming a linear drift. This leads to the depicted stepwise groundwater temperature evolution in well 6 (see Fig. 3). The Tidbit loggers that were installed in the five $1.25^{\prime \prime}$ wells showed only minor calibration offsets of $<0.1 \mathrm{~K}$. This is a highly acceptable value for field measurements on this extend and, hence, no further processing of the Tidbit-derived data was required. Groundwater temperatures were measured in different depths within each well but no relevant vertical groundwater temperature stratification was observed (see Fig. 3). Hence, the arithmetic mean of the measured groundwater temperatures at the different depths within each well for every time step was used in the further analysis. Temporal and spatial groundwater temperature evolution at the site is shown in Fig. 3, depicting the $24 \mathrm{~h}$ moving 
average of the mean groundwater temperature for each well. Minimum and maximum groundwater temperature values recorded by the Tidbit loggers in each well during each time step are additionally provided in Fig. 3 to show the limited vertical temperature variation within the individual wells. Provision of minimum and maximum temperature values is restricted to the wells equipped with the Tidbit loggers because data from wells 1 and 6 cannot be used due to the subsequent offset calibration of the logger data. Reasons for the observed similar vertical temperature distribution are the deep groundwater table ( $>20 \mathrm{~m}$ below ground surface) that is below the impact depth of the seasonal soil temperature variation (see measured groundwater temperatures at upstream wells 1 and 2 shown in Fig. 3 and soil temperature distribution shown in Fig. 4) and the confining loess-loam surface layer that inhibits heat transport by percolating surface water. Based on these findings, vertical measurement resolution in the wells was reduced in January 2017 and the monitoring campaign was continued with 24 of the initially installed 35 Tidbit loggers. Groundwater temperature monitoring was paused in wells 1 and 6 from March to May 2017 for further logger reference measurements and discontinued in well 1 in 2018 as data from well 2 was considered sufficient to characterize upstream temperatures. Additionally, groundwater temperature monitoring was paused in well 7 for a period of 4 months in 2014 due to limited logger availability. Depicted groundwater temperatures in Fig. 3 reveal a general trend of slightly rising upstream groundwater temperatures and decreasing downstream temperatures over the monitoring period. Interestingly, most wells display a different temperature pattern.

Groundwater temperature evolution in the individual wells can be summarized as follows:

- Constant groundwater temperatures of about $11.55^{\circ} \mathrm{C}$ are observed in wells 1 and 2 until January 2015. Both wells are positioned at the western boundary of the test site and are, therefore, upstream of the test site in respect to the groundwater flow. The measured temperature of $11.55^{\circ} \mathrm{C}$ is close to the mean annual air temperature for the long-term observation period 1981-2010 of the Deutscher Wetter Dienst (DWD) of $11.5^{\circ} \mathrm{C}$ measured at the DWD weather station Cologne-Stammheim (DWD 2018). Measured groundwater temperatures in upstream wells 1 and 2 are hence considered unaffected from local thermal impacts.

- After January 2015, upstream groundwater temperatures gently rise up to a maximum of $11.8^{\circ} \mathrm{C}$ in well 2. In contrast, all other wells exhibit lower initial groundwater temperatures which generally decrease across the site in direction of groundwater flow.

- At GWM 4 a slight decrease in measured groundwater temperatures to about $11.25^{\circ} \mathrm{C}$ in March 2015 is measured. After that, groundwater temperatures evolution at well 4 shows a similar temperature pattern as upstream wells with an offset of approximately $-0.3 \mathrm{~K}$.

- Measured groundwater temperatures at GWM 6 show in contrast a clear drop in temperature of $0.4 \mathrm{~K}$ until May 2014 followed by temperature recovery to $11.15^{\circ} \mathrm{C}$ with minor temperature variation in May 2017. 
- Groundwater evolution in the downstream wells 7, 8, and 9 is characterized by a general decrease in groundwater temperatures for wells 7 and 8 from $11.2{ }^{\circ} \mathrm{C}$ in June 2013 to $10.9^{\circ} \mathrm{C}$ in October 2015. During this time measured groundwater temperatures at well 9 drop from $11.4^{\circ} \mathrm{C}$ to $10.7^{\circ} \mathrm{C}$. Starting in October 2015 groundwater temperatures in wells 7 and 9 recover slowly while groundwater temperatures measured in well 8 show a constant trend towards decreasing temperature reaching a recorded minimum of $10.6^{\circ} \mathrm{C}$ in March 2018 .

In March 2018, a maximum difference of $1.2 \mathrm{~K}$ was reached between upstream and downstream temperatures. This finding presumes (a) that the gradual increase in measured upstream groundwater temperatures reflects a tendency of generally rising groundwater temperatures in the area and is not caused by a local heat source; (b) initial groundwater temperatures across at the site were the same, and (c) the measured decrease of groundwater temperatures over time across the site is in fact caused by the intensive use of shallow geothermal energy. Different indications to prove the validity of the aforementioned assumptions are presented in the following. The upstream groundwater temperature-monitoring wells 1 and 2 are located at the eastern side of a $20,000 \mathrm{~m}^{2}$ private parking space that is infrequently used. Aerial pictures that are available from the year 2003 until today do not indicate significant changes on the parking space itself or the surrounding building stock during this time period that could act as additional groundwater heat source. Furthermore, a first increase in groundwater temperatures is recorded in upstream wells 1 and 2 in January 2015 and at monitoring well 4 in March 2015. Monitoring well 4 is located $160 \mathrm{~m}$ downstream of well 2. Given the measured groundwater flow velocity of 10.8 to $13 \mathrm{~m} /$ year, the observed small time lag between onset of groundwater temperature rise in upstream well 2 and well 4 proves that the observed increase in groundwater temperature in well 4 cannot be attributed to conductive or convective heat transport from a localized upstream heat source but rather to an overall increase of groundwater temperatures in the area, e.g., caused by rising annual air temperatures. In fact, soil temperatures measured in a depth of $16.20 \mathrm{~m}$ below ground surface near monitoring well 6 verify such a rising trend (see Fig. 4). Results depicted in Fig. 3 may, at first sight, indicate an offset between upstream and downstream groundwater temperatures at the beginning of the monitoring campaign. Given the fact that a number of shallow geothermal systems were already operating prior to the installation of the monitoring network we assume that the observed difference between upstream and downstream groundwater temperatures in the early phase of the monitoring are first cooling effects resulting from the intensive use of shallow geothermal energy at the test site. This assumption is strongly supported by measured groundwater temperatures of $11.4{ }^{\circ} \mathrm{C}$ in downstream monitoring well 9 at the beginning of the monitoring campaign that is just slightly below the groundwater temperatures measured in the upstream wells 1 and 2. This confirms an initial distribution of similar groundwater temperatures across the site. While a multitude of anthropogenic impacts are known to cause increases of urban groundwater temperatures (e.g., Menberg et al. 2013b), no other reason than the intensive use of shallow geothermal energy for heating and warm water provision is found to explain a decrease of groundwater temperatures in this case. 
It is interesting to note that different groundwater temperature patterns were recorded in the wells, e.g., gradual increase of measured groundwater temperatures in wells 1 and 2 in contrast to the sinoidal temperature evolution in downstream well 9. Latter exhibits a temperature cycle wavelength of approximately 1 year indicating a direct impact from one or more operating shallow geothermal systems. This shows in general the potential influence of local impact factors, such as distance to adjacent geothermal systems or nearby water uses upon the temperature signal. Hence, small variations in well locations by just a few tens of meters lead to different recorded temperature signals (see wells 7,8 , and 9 in Fig. 3).

\section{Conclusion}

The investigated site offered very good conditions for the implementation of the monitoring campaign. Seven groundwater temperature-monitoring wells were installed and equipped with temperature loggers and a maximum temperature difference between unaffected upstream temperatures $\left(11.8{ }^{\circ} \mathrm{C}\right)$ and impacted downstream groundwater temperatures $\left(10.6{ }^{\circ} \mathrm{C}\right)$ of $1.2 \mathrm{~K}$ was recorded. It is interesting see these groundwater temperatures in comparison to historic values provided in the literature. Balke (1974) reports a groundwater temperature of $10.6{ }^{\circ} \mathrm{C}$ being measured about $1 \mathrm{~km}$ west-northwest of today's test site location. Data reported by Zhu et al. (2010) allow the quantification of the impacts of urban heat island spread due to increasing urbanization around the test site 36 years later with interpolated groundwater temperatures for the area of test site of around $12{ }^{\circ} \mathrm{C}$. This value is close to today's upstream groundwater temperatures at the test site. The measured maximum difference between unaffected upstream temperatures and impacted downstream groundwater temperatures of $1.2 \mathrm{~K}$ at the test site can be attributed to the intensive use of shallow geothermal energy. This is a very important finding as it proves that even though energy demands of the individual houses and energy extraction rates of the shallow geothermal systems are comparably small in this case, the accumulation of users eventually has a measurable impact on overall groundwater temperatures. This is interesting as the full impact of the intensive use of shallow geothermal energy on neighborhood scale is not expected to have yet fully unfolded because of the low groundwater flow velocities in relation to the limited operation period of the shallow geothermal heating systems. Long-term potential implications on the ecological and economic sustainable system operation remain hence unknown. However, not only ecological but also particularly economic aspects will at the end determine the uptake of shallow geothermal energy over conventional fossil fuel-based heating systems to successfully bring forward the decarbonization of the building sector. Therefore, a comprehensive groundwater temperature monitoring in urban areas is inevitable to obtain a clear understanding of the groundwater temperature evolution over time. While model-based studies cannot substitute the groundwater temperature monitoring, a model-based allocation of the monitoring network, especially in regards to the question of the representativeness of monitoring well locations, in the early phase of the property development is a key to obtain a full picture of urban groundwater temperature evolution. A model-based prediction of induced groundwater temperatures changes can further provide valuable information in these cases when the choice of well locations is restricted by property rights and availability of utility and unexploded 
ordnance clearances. However, model extent in combination with limited data availability causes yet high uncertainty in such model-based predictions (e.g., Schelenz et al. 2017). Key data for this case study are provided as additional download file for this article to foster future work in this area. Additional information on the test site is available upon request from the authors. All in all, results highlight the need for a coordinated geothermal development (e.g., Vienken et al. 2015), consideration of the use of shallow geothermal energy already in the early phase of urban planning and development (e.g., Schelenz et al. 2017), and management concepts (e.g., Alcaraz et al. 2016; Epting et al. 2017) to bring forward the ecological and economic sustainable intensive thermal use of the shallow subsurface.

\section{Additional file}

Additional file 1: Data file containing relevant test site information as well as hydrogeological and groundwater temperature data.

Authors' contributions

TV: led conception and design of the monitoring campaign and manuscript, substantial contributions to data analysis and interpretation; MK: led data acquisition and analysis; PD: substantial contributions to conception and design of the monitoring campaign and critical revision of the manuscript. All authors read and approved the final manuscript.

\section{Author details}

${ }^{1}$ UFZ-Helmholtz Centre for Environmental Research, Leipzig, Germany. ${ }^{2}$ Eberhard Karls University of Tübingen, Tübingen, Germany.

\section{Acknowledgements}

The authors would like to thank Rüdiger Schulz, Stefan Raab, and Frank Sohnius (Stadt Köln, Umwelt- und Verbraucherschutzamt-Immissionsschutz, Wasser- und Abfallwirtschaft) for their continuous support of this study. For the field investigations presented in this study, equipment from the UFZ MOSAIC (Model Driven Site Assessment, Information and Control) research platform was used.

\section{Competing interests}

The authors declare that they have no competing interests.

\section{Availability of data and materials}

The dataset supporting the conclusions of this article is provided as additional file for this article.

\section{Consent for publication}

Not applicable.

Ethics approval and consent to participate

Not applicable.

\section{Funding}

The presented study was partly funded through the ANGUS + Project by the German Federal Ministry of Education and Research (Förderkennzeichen 03EK3022B).

\section{Publisher's Note}

Springer Nature remains neutral with regard to jurisdictional claims in published maps and institutional affiliations.

Received: 3 September 2018 Accepted: 6 March 2019

Published online: 19 March 2019

\section{References}

Alcaraz M, García-Gil A, Vázquez-Suñé E, et al. Use rights markets for shallow geothermal energy management. Appl Energy. 2016;172:34-46.

Bakr M, Van Oostrom N, Sommer W. Efficiency of and interference among multiple aquifer thermal energy storage systems; a Dutch case study. Renewable Energy. 2013;60:53-62.

Balke KD. Der thermische Einfluss besiedelter Gebiete auf das Grundwasser, dargestellt am Beispiel der Stadt Köln. GWF-Wasser/Abwasser. 1974:115:117-24. 
Bauer S, Pfeiffer T, Boockmeyer A, et al. Quantifying induced effects of subsurface renewable energy storage. Energy Procedia. 2015;76:633-41.

Bonte M. Impacts of shallow geothermal energy on groundwater quality. A hydrochemical and geomicrobial study of the effects of ground source heat pumps and aquifer thermal energy storage. PhD-thesis. VU University Amsterdam. 2013.

Boockmeyer A, Bauer S. Efficient simulation of multiple borehole heat exchanger storage sites. Environ Earth Sci. 2016;75:1021

Brielmann H, Griebler C, Schmidt SI, et al. Effects of thermal energy discharge on shallow groundwater ecosystems. FEMS Microbiol Ecol. 2009;68:273-86.

Butler JJ. The design, performance, and analysis of slug tests. Boca Raton: Lewis Publishers; 1997.

Butler JJ. Hydrogeological methods for estimation of spatial variations in hydraulic conductivity. In: Rubin Y, Hubbard SS, editors. Hydrogeophysics. Dordrecht: Springer; 2005. p. 23-58.

Dietrich P, Leven C. Direct push-technologies. In: Kirsch R, editor. Groundwater geophysics. Berlin: Springer; 2006. p. $321-40$.

DWD. 2018. https://www.dwd.de/DE/leistungen/klimadatendeutschland/mittelwerte/temp_8110_fest_html. html?view=nasPublication. Accessed 28 Nov 2018

EGEC-European Geothermal Energy Council. EGEC Geothermal Market Report- Key Findings 2016. 2017. https:// www.egec.org/wp-content/uploads/2017/05/EGEC-Geothermal-Market-Report_KF_final_web.pdf. Accessed 29 Aug 2018.

EPA. Field analytical and site characterization technologies. Summary of Applications. Washington D.C.: EPA; 1997. p. 19.

Epting J, Handel F, Huggenberger P. Thermal management of an unconsolidated shallow urban groundwater body. Hydrol Earth Syst Sci. 2013;17:1851-69.

Epting J, García-Gil A, Huggenberger P, et al. Development of concepts for the management of thermal resources in urban areas - assessment of transferability from the Basel (Switzerland) and Zaragoza (Spain) case studies. J Hydrol. 2017:548:697-715.

Eurostat. 2018. http://ec.europa.eu/eurostat/statistics-explained/index.php?title=Energy_consumption_in_households. Accessed 29 Aug 2018.

Ferguson G, Woodbury AD. Observed thermal pollution and post-development simulations of low-temperature geothermal systems in Winnipeg, Canada. Hydrogeol J. 2006;14:1206-15.

Garrido Schneider EA, García-Gil A, Vázquez-Suñè E, et al. Geochemical impacts of groundwater heat pump systems in an urban alluvial aquifer with evaporitic bedrock. Sci Total Environ. 2016;544:354-68.

Griebler C, Kellermann C, Stumpp C et al. Auswirkungen thermischer Veränderungen infolge der Nutzung oberflächennaher Geothermie auf die Beschaffenheit des Grundwassers und seiner Lebensgemeinschaften-Empfehlungen für eine umweltverträgliche Nutzung. In: Umweltbundesamt. 2015.

Hähnlein S, Molina-Giraldo N, Blum P, et al. Ausbreitung von Kältefahnen im Grundwasser bei Erdwärmesonden. Grundwasser. 2010;15:123-33.

Hartog N. Anticipated temperature effects on biogeochemical reaction rates in seasonal aquifer thermal energy storage (ATES) systems: an evaluation using the arrhenius equation. In: 1e Nationaal Congres Bodemenergie. Utrecht, Netherlands. 2011.

Hein P, Kolditz O, Görke U-J, et al. A numerical study on the sustainability and efficiency of borehole heat exchanger coupled ground source heat pump systems. Appl Therm Eng. 2016;100:421-33.

Hermans T, Nguyen F, Klepikova M, et al. Uncertainty quantification of medium-term heat storage from short-term geophysical experiments using bayesian evidential learning. Water Resour Res. 2018:54:2931-48.

Klostermann J. Das Quartär der Niederrheinischen Bucht. Ablagerungen der letzten Eiszeit. In: Nordrhein-Westfalen GL (ed), Krefeld. 1992

Lerm S, Alawi M, Miethling-Graff R, et al. Influence of microbial processes on the operation of a cold store in a shallow aquifer: impact on well injectivity and filter lifetime. Grundwasser. 2011;16:93-104.

Leven C, Weiss H, Vienken T, et al. Direct push technologies-an efficient investigation method for subsurface characterization. Grundwasser. 2011;16:221-34.

Lienen T, Lüders K, Halm H, et al. Effects of thermal energy storage on shallow aerobic aquifer systems: temporary increase in abundance and activity of sulfate-reducing and sulfur-oxidizing bacteria. Environ Earth Sci. 2017;76:261.

Lindner M. Modellstudie zur Untersuchung induzierter Temperaturvariationen in Boden und Grundwasser durch die intensive Nutzung oberflächennaher Geothermie. Master thesis Martin-Luther-Universität Halle-Wittenberg. 2015.

Losen H. Grundwasserstände und Grundwasserbeschaffenheit im südlichen Teil der linksrheinischen Kölner Scholle: eine hydrogeologische und statistische Analyse. PhD Thesis RWTH Aachen. 1984.

Lucon O, Ürge-Vorsatz D, Zain Ahmed A et al. Buildings. In: Climate change 2014: mitigation of climate change. Contribution of working group III to the fifth assessment report of the intergovernmental panel on climate change. Cambridge: University Press; 2014.

Lund J, Sanner B, Rybach L et al. Geothermal (ground-source) heat pumps—a world overview. In: GHC Bulletin. 2004.

Margat J, Van Der Gun J. Groundwater around the world: a geographic synopsis. New York: CRC Press; 2013.

Menberg K, Bayer P, Zosseder K, et al. Subsurface urban heat islands in German cities. Sci Total Environ. 2013a;442:123-33.

Menberg K, Blum P, Schaffitel A, et al. Long-term evolution of anthropogenic heat fluxes into a subsurface urban heat island. Environ Sci Technol. 2013b;47:9747-55.

Pärisch P, Mercker O, Warmuth J, et al. Investigations and model validation of a ground-coupled heat pump for the combination with solar collectors. Appl Therm Eng. 2014;62:375-81.

Park Y, Kim N, Lee J-Y. Geochemical properties of groundwater affected by open loop geothermal heat pump systems in Korea. Geosci J. 2015;19:515-26.

Possemiers M, Huysmans M, Batelaan O. Influence of aquifer thermal energy storage on groundwater quality: a review illustrated by seven case studies from Belgium. J Hydrol. 2014;2:20-34. 
Quattrocchi F, Boschi E, Spena A, et al. Synergic and conflicting issues in planning underground use to produce energy in densely populated countries, as Italy: geological storage of $\mathrm{CO}_{2}$, natural gas, geothermics and nuclear waste disposal. Appl Energy. 2013;101:393-412.

Sanner B. Ground source heat pumps-history, development, current status, and future prospects. In: 12th IEA Heat Pump Conference. Rotterdam. 2017.

Sanner B, Karytsas C, Mendrinos D, et al. Current status of ground source heat pumps and underground thermal energy storage in Europe. Geothermics. 2003;32:579-88.

Schelenz S. Untersuchung des Einflusses ausgewählter Untergrundparameter auf die nachhaltige thermische Nutzung des oberflächennahen Untergrundes im urbanen Raum. PhD-Thesis Christian-Albrechts-University Kiel. 2017. p. 153.

Schelenz S, Vienken T, Shao H, et al. On the importance of a coordinated site characterization for the sustainable intensive thermal use of the shallow subsurface in urban areas: a case study. Environ Earth Sci. 2017:76:73.

Vienken T, Leven C, Dietrich P. Use of CPT and other direct push methods for (hydro-) stratigraphic aquifer characterization-a field study. Can Geotech J. 2012;49:197-206.

Vienken T, Reboulet E, Leven C, et al. Field comparison of selected methods for vertical soil water content profiling. J Hydrol. 2013;501:205-12.

Vienken T, Schelenz S, Rink K, et al. Sustainable intensive thermal use of the shallow subsurface-a critical view on the status quo. Groundwater. 2015;53:356-61.

Westphal A, Kleyböcker A, Jesußek A, et al. Aquifer heat storage: abundance and diversity of the microbial community with acetate at increased temperatures. Environ Earth Sci. 2017;76:66.

Younger PL. Ground-coupled heating-cooling systems in urban areas. How sustainable are they? Bull Sci Technol Soc 2008;28:174-82.

Zhu K, Blum P, Ferguson G, et al. The geothermal potential of urban heat islands. Environ Res Lett. 2010:5:044002

Zlotnik VA, Mcguire VL. Multi-level slug tests in highly permeable formations: 1. Modification of the Springer-Gelhar (SG) model. J Hydrol. 1998;204:271-82.

\section{Submit your manuscript to a SpringerOpen ${ }^{\circ}$ journal and benefit from:}

- Convenient online submission

- Rigorous peer review

- Open access: articles freely available online

- High visibility within the field

- Retaining the copyright to your article

Submit your next manuscript at $\boldsymbol{\nabla}$ springeropen.com 